\title{
PENENTUAN KUALITAS MUTU BERAS MERAH BERDASARKAN STANDART NASIONAL INDONESIA BERBASIS PENGOLAHAN CITRA DIGITAL
}

\author{
Elly Antika ${ }^{1}$, Hariyono Rakhmad ${ }^{2}$, Febri Nabilla Ishaq ${ }^{3}$ \\ 1,2 Jurusan Tekonologi Informasi, ${ }^{3}$ Politeknik Negeri Jember \\ 1ellyantika@polije.ac.id, ${ }^{2}$ harierahmat93@gmail.com,3 febrinabilla.ishaq@gmail.com
}

\begin{abstract}
Abstrak
Beras merah baik bagi kesehatan tubuh, karena menimbulkan rasa kenyang lebih lama, melancarkan sistem pencernaan, mengandung mineral penting untuk menepis radikal bebas, mengandung vitamin B6, menurunkan kadar kolesterol tubuh, lalu mencegah penyakit jantung. Namun dalam produksinya beras merah perlu kita klasifikasi kualitas mutunya. Saat ini pemeriksaan kualitas beras merah telah dilakukan secara manual oleh ahli pertanian organik dan pengawas pemeriksa yang berpengalaman. Hal ini memiliki kelemahan karena adanya subjektivitas penilaian kualitas antara pengamat yang satu dengan lainnya, inkonsistensi, dan memerlukan waktu yang lebih. Oleh karena itu, diperlukan cara untuk menentukan klasifikasi kualitas beras merah dengan cepat, akurat, dan mudah untuk dioperasikan sehingga meningkatakan efisiensi pengukuran kualitas beras merah. Sehingga penelitian ini menggunakan pengelolahan citra digital dapat mengklasifikasi kualitas mutu beras merah berdasarkan SNI dengan metode Binerisasi (Thresholding), Median Filtering, dan Connected Component Labelling. Sehingga didapatkan hasil pendeteksian pada pengukuran dan bentuk beras merah yang sangat akurat untuk mendapatkan kualitas yang sesuai dengan data yang telah dikumpulkan. Tingkat akurasi pada penggunaan kualitas beras merah dengan jarak $10 \mathrm{~cm}$ dari objek ke kamera sebesar $80 \%$ sedangkan tingkat akurasi pada penggunaan kualitas beras merah dengan jarak $15 \mathrm{~cm}$ dari objek ke kamera sebesar $100 \%$.
\end{abstract}

Kata kunci: kualitas beras, beras merah, standar SNI, mutu beras merah

\section{Pendahuluan}

Beras merah baik bagi kesehatan tubuh, karena menimbulkan rasa kenyang lebih lama, melancarkan sistem pencernaan, mengandung mineral penting untuk menepis radikal bebas, mengandung vitamin B6, menurunkan kadar kolesterol tubuh, lalu mencegah penyakit jantung. Dalam produksinya beras merah perlu kita klasifikasi kualitas mutunya. Saat ini pemeriksaan kualitas beras merah telah dilakukan secara manual oleh ahli pertanian organik dan pengawas pemeriksa yang berpengalaman. Cara ini memiliki kelemahan karena adanya subjektivitas penilaian kualitas antara pengamat yang satu dengan pengamat yang lain, inkonsistensi, dan memerlukan waktu yang lebih. Oleh karena itu, diperlukan cara untuk menentukan klasifikasi kualitas beras merah dengan cepat, akurat, dan mudah untuk dioperasikan sehingga meningkatakan efisiensi pengukuran kualitas beras merah. Dengan menggunakan pengelolahan citra digital dapat mengklasifikasi kualitas mutu beras merah berdasarkan SNI dengan metode Binerisasi (Thresholding), Median Filtering, dan Connected Component Labelling.

\section{Tinjauan Pustaka}

Ukuran Panjang dan Bentuk Bulir Beras Merah Sesuai Standart Iso

a. Pengukuran Panjang Beras

Sesuai data Standart Iso pada Buletin Teknik Pertanian Vol. 15, No. 1, 2010: 1-5 yakni
Teknik Evaluasi Mutu Beras Ketan dan Beras Merah Pada Beberapa Galur Padi Gogo menyatakan berdasarkan ukuran, beras digolongkan ke dalam empat tipe, yaitu beras berukuran sangat panjang $(>7,50 \mathrm{~mm})$, panjang $(\mathrm{L}=6,61-7,50 \mathrm{~mm})$, sedang $(\mathrm{M}=5,51-6,60$ $\mathrm{mm})$, dan pendek $(\mathrm{S}=<5,50 \mathrm{~mm})$. pengukuran dilakukan pada 10 butir sampel beras utuh, diukur panjangnya dengan menggunakan alat pengukur dial caliper. Data yang diperoleh dibuat rata-ratanya dan dicatat pada buku daftar galur.

b. Pengukuran Bentuk Beras

Bentuk beras dibagi kedalam tiga kelompok, yaitu ramping $(\mathrm{S}=>3,0)$, sedang $(\mathrm{M}=2,1$ $3,0)$, dan bulat $(\mathrm{B}=1,0-2,0)$. Bentuk beras ditetapkan berdasarkan rasio panjang dan lebar beras dengan menggunakan rumus sebagai berikut:

$$
\text { Bentuk Beras }=\frac{\text { Purlury Berus }}{\text { Lebar Beras }}
$$

Standar beras pemerintah adalah meliputi minimal 95\% tingkat penggilingan; maksimum 20\% rusak, butir menir maksimum $2 \%$ dan maksimum kadar air 14\%. standart nasional Indonesia menggunakan menggunakan fisik beras yakni pengukuran warna, bentuk dan ukuran beras merah Fibriyanti (2012).

Proses penentuan klasifikasi beras merah mengikuti tahapan proses sebagai berikut: 
- Binerisasi (tresholding)

- Median filtering

- Connected componen labeling

- Klasifikasi kualitas beras merah

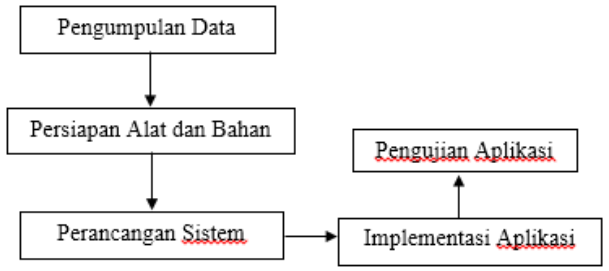

Gambar 1. Metode Penelitian

3. Metode Penelitian

Metode penelitian yang digunakan dalam penelitian ini digambarkan dalam Gambar 1.

a. Pengumpulan Data

Pengambilan data beras merah dilakukan pada Ketua Tani Jaya II Desa Rowosari Kecamatan Sumberjambe Kabupaten Jember.

b. Persiapan alat dan bahan

Alat yang digunakan dalam penelitian ini adalah komputer dan kamera telepon pintar 8Mp.

c. Perancangan sistem

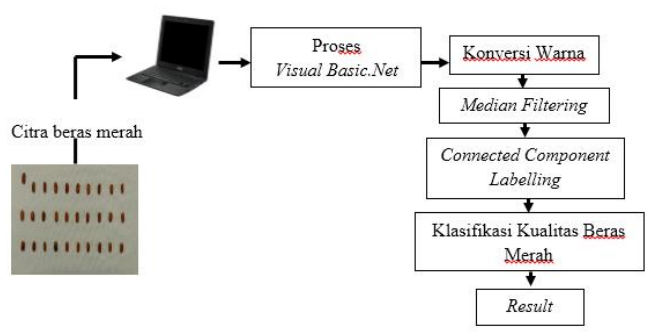

Gambar 2. Proses pembuatan aplikasi

d. Implementasi aplikasi

Tahapan implementasi aplikasi ini dilakukan dengan memasukan citra dari beras merah yang telah disiapkan, lalu diproses kedalam visual basic.net selanjutnya citra beras merah akan dikonversi warnanya dengan metode tresholding, lalu akan di median filtering untuk menghilangkan noise yang ada pada citra beras merah yang telah di binerisasi serta meningkatkan kualitas pada citra, selanjutnya akan diproses dengan menggunakan metode connected component labelling untuk mendeteksi banyaknya jumlah objek yang terdeteksi, kemudian pengisian panjang beras pada aplikasi dan dilanjutkan ke proses kualitas beras yang berguna untuk mendeteksi panjang, lebar, bentuk pada beras merah serta mengklasiikasi kualitas pada objek yang kemudian dilanjutkan data pada result. e. Pengujian aplikasi

Pengujian aplikasi dilakukan untuk laluan pengecekan terhadap hasil masing-masing proses pada penentuan klasifikasi mutu beras merah.

\section{Hasil dan Pembahasan}

4.1 Hasil proses thresholding

Tresholding akan mengubah citra derajat keabuan menjadi citra biner atau hitam putih sehingga dapat diketahui daerah mana yang termasuk objek dan background dari citra secara jelas.

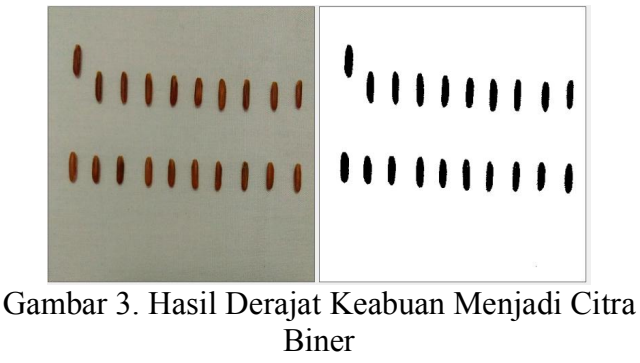

\subsection{Hasil proses Median filtering}

Median filtering ini akan menghasilkan citra dengan meningkatkan kualitas citra. Sehingga memperjelas daerah tepi (edge) pada gambar. Pada median filtering ini bahwa proses penghalusanya terjadi pada daerah tepi gambar, sehingga meski terjadi penghalusan gambar.

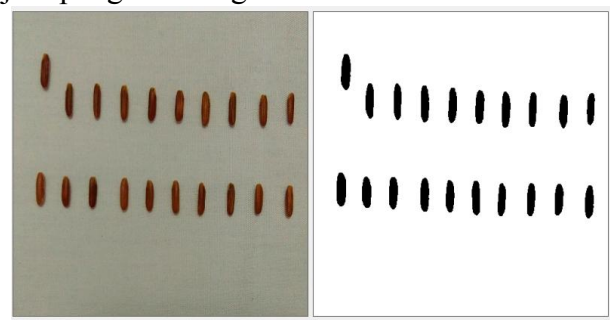

Gambar 4. Hasil Peningkatan Kualitas Citra Menggunakan Median Filtering

4.3 Hasil proses Connected Component Labelling

Jumlah beras dengan menghasilkan nilai kedalam aplikasi dengan jumlah beras merah yang telah terdeteksi. Seperti pada Gambar 5.

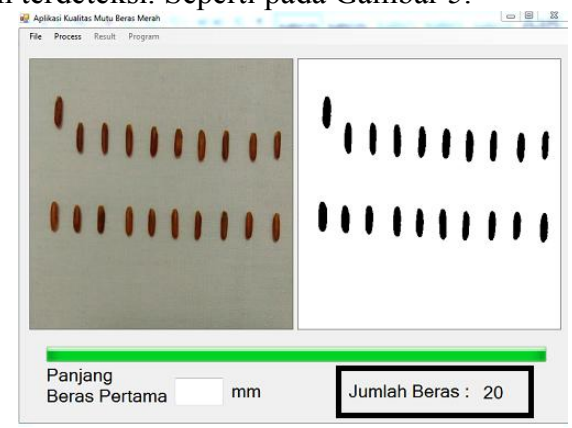

Gambar 5. Hasil Jumlah Beras Yang Terdeteksi 


\subsection{Hasil Process Kualitas Beras}

Pada proses kualitas beras, sebelum proses dijalankan, aplikasi ini akan memerintahkan untuk mengisi inisialisasi panjang beras dalam bentuk millimeter, tujuannya sebagai pembacaan millimeter pada citra beras merah agar tetap konsisten.

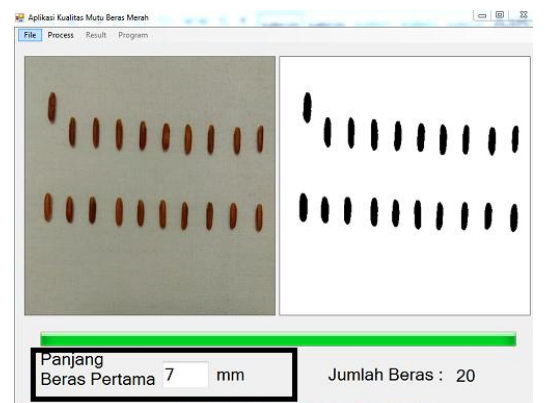

Gambar 6. Pengisian Panjang Beras Millimeter

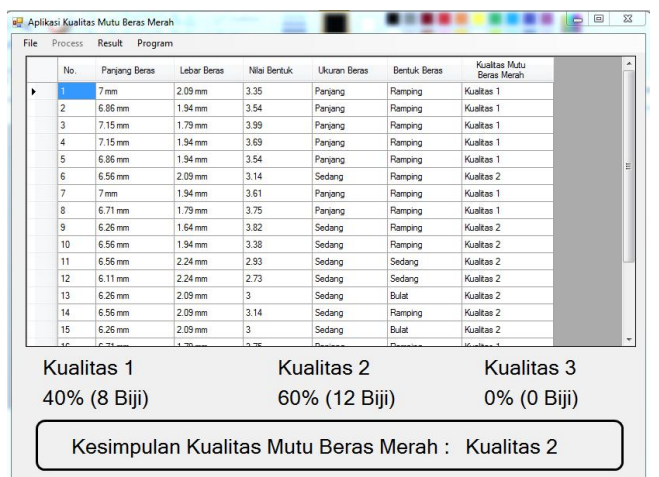

Gambar 7. Tampilan Pengujian Akhir Pada Result

Tabel 1.

Hasil Klasifikasi Kualitas Mutu Beras Merah Berdasarkan SNI Berbasis Pengolahan Citra

\begin{tabular}{|c|c|c|}
\hline & & \\
KUALITAS 1 & KUALITAS 2 & KUALITAS 3 \\
\hline & & \\
$15 \%$ & & $25 \%$ \\
$(3 \mathrm{biji})$ & $60 \%(12 \mathrm{biji})$ & $(5 \mathrm{biji})$ \\
\hline
\end{tabular}

\subsection{Hasil Uji Coba Kualitas Beras}

Banyaknya butir dengan kondisi utuh dapat menghasilkan jarak dan jumlah butir beras yang optimal pada pengambilan citra dari beras merah yang telah diuji coba pada Tabel 1 Pengujian Aplikasi dengan kualitas standart biji beras merah yakni dengan menggunakan kualitas 2 pada citra beras merah.

\subsubsection{Hasil Pengujian Beras Merah Menggunakan Jarak $10 \mathrm{~cm}$ dan $15 \mathrm{~cm}$ pada Objek ke Kamera}

Pada tahap ini dilakukan pembacaan butir beras merah untuk uji coba dengan jarak obyek ke kamera $10 \mathrm{~cm}$ dan $15 \mathrm{~cm}$ menggunakan jumlah butir beras merah 10 biji, 15 biji, 20 biji, 25 biji, 30 biji. Adapun hasilnya sebagai berikut:

Tabel 2.

Pengambilan Gambar Dengan Jarak Obyek Ke Kamera $10 \mathrm{~cm}$

\begin{tabular}{|c|c|c|c|}
\hline $\begin{array}{c}\text { No } \\
\text { mer }\end{array}$ & $\begin{array}{c}\text { Jumlah } \\
\text { Butir }\end{array}$ & $\begin{array}{c}\text { Kualitas } \\
\text { Standart }\end{array}$ & $\begin{array}{c}\text { Pembacaan } \\
\text { Menggunakan } \\
\text { Aplikasi }\end{array}$ \\
\hline 1 & 10 biji & 2 & 1 \\
\hline 2 & 15 biji & 2 & 1 \\
\hline 3 & 20 biji & 2 & 2 \\
\hline 4 & 25 biji & 2 & 1 \\
\hline 5 & 30 biji & 2 & 2 \\
\hline
\end{tabular}

Keterangan :

Dalam pengujian jarak $10 \mathrm{~cm}$ diketahui tingkat error sebanyak $49,9 \%$ pada pengujian 10 biji, 15 biji, 25 biji dari 30 butir beras merah yang diujikan. Maka dari itu tingkat akurasi yang didapatkan dari hasil pengujian tersebut sebesar $50,1 \%$ pada pengujian 20 biji dan 30 biji beras merah.

Tabel 3.

Pengambilan Gambar Dengan Jarak Obyek Ke Kamera $15 \mathrm{~cm}$

\begin{tabular}{|c|c|c|c|}
\hline $\begin{array}{c}\text { No } \\
\text { mer }\end{array}$ & $\begin{array}{c}\text { Jumlah } \\
\text { Butir }\end{array}$ & $\begin{array}{c}\text { Kualitas } \\
\text { Standart }\end{array}$ & $\begin{array}{c}\text { Pembacaan } \\
\text { Menggunakan } \\
\text { Aplikasi }\end{array}$ \\
\hline 1 & 10 biji & 2 & 2 \\
\hline 2 & 15 biji & 2 & 2 \\
\hline 3 & 20 biji & 2 & 2 \\
\hline 4 & 25 biji & 2 & 2 \\
\hline 5 & 30 biji & 2 & 2 \\
\hline
\end{tabular}

Keterangan :

Dalam percobaan pada Tabel 3 diketahui tingkat error sebesar 0\% didapat pada jumlah butir 10 biji, 15 biji, 20 biji, 25 biji, 30 biji dan tingkat akurasi $100 \%$ dari jarak obyek $15 \mathrm{~cm}$.

\subsubsection{Pembacaan Jarak $10 \mathrm{~cm}$ Beras Merah ke Kamera}

Pada tahap ini dilakukan penentuan jarak optimal objek ke kamera $10 \mathrm{~cm}$ dengan percobaan sebanyak 10 biji, 15 biji, 20 biji, 25 biji, 30 biji dan penentuan panjang beras $7 \mathrm{~mm}, 6 \mathrm{~mm}, 5 \mathrm{~mm}$.

Tabel 4.

Pengujian 10 Biji Beras Merah Menggunakan Jarak Objek Ke Kamera $10 \mathrm{~cm}$

\begin{tabular}{|c|c|c|}
\hline $\begin{array}{c}\text { Panjang } \\
\text { Beras }\end{array}$ & Kualitas Standart & Hasil Percobaan \\
\hline $7 \mathrm{~mm}$ & 2 & 1 \\
\hline
\end{tabular}


Volume 4, Edisi 2, Februari 2018

\begin{tabular}{|c|c|c|}
\hline $\begin{array}{c}\text { Panjang } \\
\text { Beras }\end{array}$ & Kualitas Standart & Hasil Percobaan \\
\hline $6 \mathrm{~mm}$ & 2 & 2 \\
\hline $5 \mathrm{~mm}$ & 2 & 2 \\
\hline
\end{tabular}

Keterangan:

Dalam pengujian pada Tabel 4 diketahui tingkat error didapatkan pada panjang beras sebesar $7 \mathrm{~mm}$, hal ini berarti tingkat ke eroran didapatkan pada hasil percobaan 10 biji beras merah dengan pembacaan jarak $10 \mathrm{~cm}$ dari objek beras merah sebesar $10 \%$. Maka dari itu tingkat akurasi yang didapatkan dari hasil percobaan tersebut sebesar $90 \%$ termasuk dalam kualitas 2 yang terdapat pada panjang beras merah $6 \mathrm{~mm}$ dan $5 \mathrm{~mm}$.

Tabel 5.

Pengujian 15 Biji Beras Merah Menggunakan Jarak Objek Ke Kamera $10 \mathrm{~cm}$

\begin{tabular}{|c|c|c|}
\hline $\begin{array}{c}\text { Panjang } \\
\text { Beras }\end{array}$ & $\begin{array}{c}\text { Kualitas } \\
\text { Standart }\end{array}$ & $\begin{array}{c}\text { Hasil } \\
\text { Percobaan }\end{array}$ \\
\hline $7 \mathrm{~mm}$ & 2 & 1 \\
\hline $6 \mathrm{~mm}$ & 2 & 2 \\
\hline $5 \mathrm{~mm}$ & 2 & 2 \\
\hline
\end{tabular}

Keterangan :

Dalam pengujian pada Tabel 5 diketahui tingkat error didapatkan pada panjang beras sebesar $7 \mathrm{~mm}$, hal ini berarti tingkat ke eroran didapatkan pada hasil percobaan 15 biji beras merah dengan pembacaan jarak $10 \mathrm{~cm}$ dari objek beras merah sebesar $10 \%$. Maka dari itu tingkat akurasi yang didapatkan dari hasil percobaan tersebut sebesar $90 \%$ termasuk dalam kualitas 2 yang terdapat pada panjang beras merah $6 \mathrm{~mm}$ dan $5 \mathrm{~mm}$.

Tabel 6.

Pengujian 20 Biji Beras Merah Menggunakan Jarak Objek Ke Kamera $10 \mathrm{~cm}$

\begin{tabular}{|c|c|c|}
\hline Panjang Beras & Kualitas Standart & Hasil Percobaan \\
\hline $7 \mathrm{~mm}$ & 2 & 2 \\
\hline $6 \mathrm{~mm}$ & 2 & 2 \\
\hline $5 \mathrm{~mm}$ & 2 & 2 \\
\hline
\end{tabular}

Keterangan :

Dalam pengujian pada Tabel 6 diketahui tingkat error sebesar $0 \%$ dan tingkat akurasi $100 \%$ pada pengambilan jarak $10 \mathrm{~cm}$ dengan jumlah beras 20 biji dan pada penentuan panjang beras $7 \mathrm{~mm}, 6 \mathrm{~mm}$, $5 \mathrm{~mm}$.
Tabel 7.

Pengujian 25 Biji Beras Merah Menggunakan Jarak Objek Ke Kamera $10 \mathrm{~cm}$

\begin{tabular}{|c|c|c|}
\hline $\begin{array}{c}\text { Panjang } \\
\text { Beras }\end{array}$ & $\begin{array}{c}\text { Kualitas } \\
\text { Standart }\end{array}$ & $\begin{array}{c}\text { Hasil } \\
\text { Percobaan }\end{array}$ \\
\hline $7 \mathrm{~mm}$ & 2 & 1 \\
\hline $6 \mathrm{~mm}$ & 2 & 2 \\
\hline $5 \mathrm{~mm}$ & 2 & 2 \\
\hline
\end{tabular}

Keterangan :

Dalam pengujian pada Tabel 7 diketahui tingkat error didapatkan pada panjang beras sebesar $7 \mathrm{~mm}$, hal ini berarti tingkat ke eroran didapatkan pada hasil percobaan 25 biji beras merah dengan pembacaan jarak $10 \mathrm{~cm}$ dari objek beras merah sebesar $10 \%$. Maka dari itu tingkat akurasi yang didapatkan dari hasil percobaan tersebut sebesar $90 \%$ termasuk dalam kualitas 2 yang terdapat pada panjang beras merah $6 \mathrm{~mm}$ dan $5 \mathrm{~mm}$.

Tabel 8.

Pengujian 30 Biji Beras Merah Menggunakan Jarak Objek Ke Kamera $10 \mathrm{~cm}$

\begin{tabular}{|c|c|c|}
\hline $\begin{array}{c}\text { Panjang } \\
\text { Beras }\end{array}$ & $\begin{array}{c}\text { Kualitas } \\
\text { Standart }\end{array}$ & $\begin{array}{c}\text { Hasil } \\
\text { Percobaan }\end{array}$ \\
\hline $7 \mathrm{~mm}$ & 2 & 2 \\
\hline $6 \mathrm{~mm}$ & 2 & 2 \\
\hline $5 \mathrm{~mm}$ & 2 & 2 \\
\hline
\end{tabular}

Keterangan :

Dalam pengujian pada Tabel 8 diketahui tingkat error sebesar $0 \%$ dan tingkat akurasi $100 \%$ pada pengambilan jarak $10 \mathrm{~cm}$ dengan jumlah beras 30 biji dan pada penentuan panjang beras $7 \mathrm{~mm}, 6 \mathrm{~mm}$, $5 \mathrm{~mm}$.

\subsubsection{Pembacaan Jarak $15 \mathrm{~cm}$ Beras Merah ke Kamera}

Pada tahap ini dilakukan penentuan jarak optimal objek ke kamera $15 \mathrm{~cm}$ dengan percobaan sebanyak 10 biji, 15 biji, 20 biji, 25 biji, 30 biji dan penentuan panjang beras $7 \mathrm{~mm}, 6 \mathrm{~mm}, 5 \mathrm{~mm}$.

Tabel 9.

Pengujian 10 Biji Beras Merah Menggunakan Jarak Objek Ke Kamera $15 \mathrm{~cm}$

\begin{tabular}{|c|c|c|}
\hline $\begin{array}{c}\text { Panjang } \\
\text { Beras }\end{array}$ & $\begin{array}{c}\text { Kualitas } \\
\text { Standart }\end{array}$ & $\begin{array}{c}\text { Hasil } \\
\text { Percobaan }\end{array}$ \\
\hline $7 \mathrm{~mm}$ & 2 & 2 \\
\hline $6 \mathrm{~mm}$ & 2 & 2 \\
\hline $5 \mathrm{~mm}$ & 2 & 2 \\
\hline
\end{tabular}


Keterangan :

Dalam pengujian pada Tabel 9 diketahui tingkat error sebesar $0 \%$ dan tingkat akurasi $100 \%$ pada pengambilan jarak $15 \mathrm{~cm}$ dengan jumlah beras 10 biji dan pada penentuan panjang beras $7 \mathrm{~mm}, 6$ $\mathrm{mm}, 5 \mathrm{~mm}$.

Tabel 10.

Pengujian 15 Biji Beras Merah Menggunakan Jarak

\begin{tabular}{|c|c|c|}
\hline \multicolumn{3}{|c|}{ Objek Ke Kamera $15 \mathrm{~cm}$} \\
\hline $\begin{array}{c}\text { Panjang } \\
\text { Beras }\end{array}$ & $\begin{array}{c}\text { Kualitas } \\
\text { Standart }\end{array}$ & $\begin{array}{c}\text { Hasil } \\
\text { Percobaan }\end{array}$ \\
\hline $7 \mathrm{~mm}$ & 2 & 2 \\
\hline $6 \mathrm{~mm}$ & 2 & 2 \\
\hline $5 \mathrm{~mm}$ & 2 & 2 \\
\hline
\end{tabular}

Keterangan :

Dalam pengujian pada Tabel 10 diketahui tingkat error sebesar $0 \%$ dan tingkat akurasi $100 \%$ pada pengambilan jarak $15 \mathrm{~cm}$ dengan jumlah beras 15 biji dan pada penentuan panjang beras $7 \mathrm{~mm}, 6$ $\mathrm{mm}, 5 \mathrm{~mm}$.

Tabel 11.

Pengujian 20 Biji Beras Merah Menggunakan Jarak Objek Ke Kamera $15 \mathrm{~cm}$

\begin{tabular}{|c|c|c|}
\hline $\begin{array}{c}\text { Panjang } \\
\text { Beras }\end{array}$ & $\begin{array}{c}\text { Kualitas } \\
\text { Standart }\end{array}$ & $\begin{array}{c}\text { Hasil } \\
\text { Percobaan }\end{array}$ \\
\hline $7 \mathrm{~mm}$ & 2 & 2 \\
\hline $6 \mathrm{~mm}$ & 2 & 2 \\
\hline $5 \mathrm{~mm}$ & 2 & 2 \\
\hline
\end{tabular}

Keterangan :

Dalam pengujian pada Tabel 12 diketahui tingkat error sebesar 0\% dan tingkat akurasi 100\% pada pengambilan jarak $15 \mathrm{~cm}$ dengan jumlah beras 20 biji dan pada penentuan panjang beras $7 \mathrm{~mm}, 6$ $\mathrm{mm}, 5 \mathrm{~mm}$.

Tabel 12.

Pengujian 25 Biji Beras Merah Menggunakan Jarak Objek Ke Kamera $15 \mathrm{~cm}$

\begin{tabular}{|c|c|c|}
\hline $\begin{array}{c}\text { Panjang } \\
\text { Beras }\end{array}$ & $\begin{array}{c}\text { Kualitas } \\
\text { Standart }\end{array}$ & $\begin{array}{c}\text { Hasil } \\
\text { Percobaan }\end{array}$ \\
\hline $7 \mathrm{~mm}$ & 2 & 2 \\
\hline $6 \mathrm{~mm}$ & 2 & 2 \\
\hline $5 \mathrm{~mm}$ & 2 & 2 \\
\hline
\end{tabular}

Keterangan :

Dalam pengujian pada Tabel 12 diketahui tingkat error sebesar 0\% dan tingkat akurasi 100\% pada pengambilan jarak $15 \mathrm{~cm}$ dengan jumlah beras 25 biji dan pada penentuan panjang beras $7 \mathrm{~mm}, 6$ $\mathrm{mm}, 5 \mathrm{~mm}$.
Tabel 13.

Pengujian 30 Biji Beras Merah Menggunakan Jarak

\begin{tabular}{|c|c|c|}
\hline $\begin{array}{c}\text { Panjang } \\
\text { Beras }\end{array}$ & $\begin{array}{c}\text { Kualitas } \\
\text { Standart }\end{array}$ & $\begin{array}{c}\text { Hasil } \\
\text { Percobaan }\end{array}$ \\
\hline $7 \mathrm{~mm}$ & 2 & 2 \\
\hline $6 \mathrm{~mm}$ & 2 & 2 \\
\hline $5 \mathrm{~mm}$ & 2 & 2 \\
\hline
\end{tabular}

Keterangan :

Dalam pengujian pada tabel 13 diketahui tingkat error sebesar $0 \%$ dan tingkat akurasi $100 \%$ pada pengambilan jarak $15 \mathrm{~cm}$ dengan jumlah beras 30 biji dan pada penentuan panjang beras $7 \mathrm{~mm}, 6$ $\mathrm{mm}, 5 \mathrm{~mm}$.

Dari pengujian didapatkan :

1. Jarak pengambilan gambar optimal dari objek ke kamera yakni $15 \mathrm{~cm}$.

2. Jumlah butir beras merah yang optimal sebanyak 10 biji, 15 biji, 20 biji, 25 biji dan 30 biji, dengan jarak pengambilan gambar $15 \mathrm{~cm}$. Pengambilan gambar dilakukan pada kondisi tidak terlalu terang dan tidak terlalu redup untuk membatasi derajat pengambilan foto yang kurang tepat atau terdapat noise dan juga membatasi bayangan yang ada pada citra.

\section{Kesimpulan}

Berdasarkan hasil penelitian ini dapat disimpulkan :

a. Dengan mengkonversikan citra beras merah menjadi citra biner (tresholding), memproses median filtering menghasilkan citra dengan meningkatkan kualitas citra, membangun metode connected component labelling menghasilkan perhitungan jumlah biji beras merah yang terdeteksi oleh metode tersebut secara akurat,

b. Pengujian hasil aplikasi klasifikasi kualitas mutu beras merah berdasarkan standart nasional indonesia didapatkan hasil pendeteksian pada pengukuran dan bentuk beras merah yang sangat akurat untuk mendapatkan kualitas yang sesuai dengan data yang telah dikumpulkan.

c. Tingkat akurasi pada penggunaan kualitas beras merah dengan jarak $10 \mathrm{~cm}$ dari objek ke kamera sebesar $80 \%$ dengan sampel bulir sebanyak 10 biji, 15 biji, 20 biji, 25 biji, 30 biji. Sedangkan tingkat akurasi pada penggunaan kualitas beras merah dengan jarak $15 \mathrm{~cm}$ dari objek ke kamera sebesar $100 \%$ dengan sampel bulir sebanyak 10 biji, 15 biji, 20 biji, 25 biji, 30 biji. 


\section{Daftar Pustaka:}

Fibriyanti, Y, (2012), “Kajian Kualitas Kimia dan Biologi Beras Merah Dalam Beberapa Pewadah Pewadahan Selama Penyimpanan", https://www.scribd.com/document/354829712/ Pengujian-mutu-beras-merah-dalam-beberapakemasan. [ 1 Juli ].

Silvi, A. Yudho, D. Santoso, H. Marnasusanto, N. Tirtana, A. Khusnu, F, (2012), "Clustering Kualitas Beras Berdasarkan Ciri Fisik Menggunakan Metode K-Means", http:/yudistira.lecture.ub.ac.id/files/2014/04/ clustering-kualitas-beras-dengan-k-means.pdf. [ 27 Februari].

Nurcahyani, A. Saptono, R, (2015), "Identifikasi Kualitas Beras dengan Citra Digital”, http://journal.unnes.ac.id/nju/index.php/sji. [20 Desember 2016].

Permana, R, (2015), "Pengertian Citra dan Pengolahan Citra”, http://www.romlisapermana.com. [25 Maret 2016].

Rakhmad, Hariyono, (2015), "Kuliah Ke 4 Pengolahan Citra Berwarna”, https://www.scribd.com/doc/281563621/Kulia h-Ke-4-Pengolahan-Citra-Berwarna. Agustus 2017].

Santika, A. Rozakurniati, (2010), "Teknik Evaluasi Mutu Beras Ketan dan Beras Merah pada Beberapa Galur Padi Gogo", Bulletin Teknik Pertanian Vol. 15(1): 1-5. [1 Maret].

Suminar, R. Hidayah, B. Atmaja, D. "Klasifikasi Kualitas Beras Berdasarkan Ciri Fisik Berbasis Pengolahan Citra Digital”.' https:// openlibrary.telkomuniversity.ac.id/pustaka/file s/92748/resume/klasifikasi-kualitas-berasberdasarkan-ciri-fisik-berbasis-pengolahancitra-digital.pdf. 